Uniwersytet w Białymstoku

Wydział Filologiczny

Kolegium Językoznawstwa

tel.: + 48857457450

e-mail: maximovitch@interia.pl

ORCID ID: https://orcid.org/0000-0001-9222-6290

\title{
Современные исследования и различные подходы к изучению библеизмов в русском языке
}

Ключевые слова: Библия, русский язык, библейская фразеология, лингвистические исследования, национальная культура

Исследование языка Библии представляет собой увлекательный, но одновременно и сложный процесс. В данной области довольно много нерешенных проблем и вопросов, на которые современные лингвисты пробуют найти ответ. Изучение Библии российскими учеными находится под влиянием выбора определенного подхода к данной проблеме: какой путь следует избрать, на чем основываться и какие методы использовать, приступая к изучению библейской тематики. В современных российских лингвистических трудах обозначились два направления в изучении фразеологизмов библейского происхождения: отечественное и западническое. И в связи с этим появились два противоположных мнения, касательно вышеуказанной проблемы. Соответственно и представители ученых кругов руководствуются в своей деятельности разными принципами. Одни считают, что семьдесят лет правления советской власти - это время «тишины» и бездействия в деле исследования Священного Писания. Поэтому, не сохранив традиций и утратив исследовательские навыки при работе с ним, теперь необходимо возобновить приостановленные исследования и обратиться к западным ученым, которые все это время продолжали активную дея- 
тельность в данной сфере, а также заимствовать их идеи и подражать их методам. В конце XX века в России появляются труды зарубежных библеистов, переведенные на русский язык [см.: Библейские исследования 1997]. Цель таких изданий - познакомить «обделенных» российских ученых с результатами последних научных изысканий в области изучения Библии.

В свою очередь, представители отечественного направления придерживаются прямо противоположной точки зрения. Свои работы они основывают на собственных традициях, а также на достижениях русской лингвистической школы, роль которой несомненно велика, несмотря на заметное затишье в деле изучения Священного Писания.

Ученые, выступающие за продолжение собственных традиций, считают, что было бы непростительно нарушать уже существующую на протяжении многих лет (нескольких веков) преемственность и искусственно внедрять в русскую науку чужие методы и идеи без учета ее национальных особенностей, а также не принимать во внимание сложившуюся в России ситуацию восстановления культурных и духовных традиций и ценностей. В северной столице России Санкт-Петербурге известна деятельность Русской Северо-Западной Библейской Комиссии (РБК), созданной в 1915 году. После долгого перерыва она в 1995 году активизировала свою работу. РБК занималась изданием публикаций, содержащих материалы конференций библейской тематики, предоставляла доступ к архивным материалам советского времени и просто публиковала работы, посвященные вопросам изучения Библии, а также ее переводы на русский язык [см.: Известия Библейских Комиссий 1990, 1991; Комиссия по научному изданию Славянской Библии 1990; Ларсон 1993; Переводы Библии и их значение в развитии духовной культуры славян 1990; Библия 1998 и др.]. Ученые - представители РБК считали, что необходимо оценить, осознать и направить в нужную сторону влияние русских текстов на формирование современной ментальности российского общества и при этом подчеркивали, что «обязательными предпосылками этого являются как осознание теснейшей связи семантики и стиля, так и осознание невозможности замены традиционных русских библейских текстов современными» [см.: Библия и возрождение духовной культуры русского и других славянских народов 1995].

Члены РБК являлись представителями отечественного направления. В своей деятельности они ориентировались на сложившейся в России традиции исследования Священного Писания, но, несмотря на это, 
проявляли большой интерес к многочисленным достижениям западных ученых и не всегда открыто пренебрегали критикой «западников».

Тематика публикуемых исследователями Библии работ довольно разнообразная. Некоторые работы рассчитаны на широкий круг читателей и трактуют библейскую мудрость [см.: Губанов 1996], другие помогают ориентироваться в текстах Библии [см.: Библейская энциклопедия 1996].

Целый ряд научных работ посвящен библеизмам. Прежде всего это статьи общего характера, авторы которых указывают на происхождение и пути проникновения библеизмов в русский язык [см.: Климович 2006; Григорьев 2007, 52-58), изучают, какие языковые единицы входят в их состав [см.: Верещагин 1993, 90-98], рассматривают библеизмы в контексте национальной культуры и с учетом особенностей духовного развития общества [см.: Лилич 1995] или знакомят читателя с употреблением фразеологических единиц библейского происхождения в современных текстах [см.: Мокиенко 1995, 143-158]. Ведущий языковед Мокиенко, как явный представитель отечественного направления, приводимыми примерами и рассуждениями доказывает, что система библейских фразеологизмов в советскую эпоху совершенно не пострадала. Более того, в своей статье он указывает на причины высокой динамичности библеизмов и рассматривает разнообразные способы их адаптации к контексту и к конкретному языку.

Истории библейских фразеологизмов и их укреплению в системе русского языка посвящена статья Бирих и Матешича, в которой авторы пробуют классифицировать библеизмы по их происхождению, затрагивают проблему видоизменения формы и значения данных языковых единиц, подчеркивают отсутствие или наличие связи библеизма с первоисточником [см.: Бирих, Матешич 1998].

Исследования некоторых лингвистов носят сопоставительный характер. Интересны работы Гака, в которых автор занимается сопоставительным анализом библейских фразеологизмов русского и французского языков, затрагивает библеизмы, функционирующие в испанском и английском языках, выдвигает ряд критериев для сопоставления библейских высказываний и предлагает способ классификации библейских фразеологизмов с точки зрения их соотношения с текстом Библии [см.: Гак 1997, 1999]. Языковед Бетехтина, в свою очередь, исследует различия в употреблении библеизмов на примере русского и английского языков. Она акцентирует свое внимание на антропонимическом компоненте библейского происхождения, вспоминая о ряде экстралингвистических и лингвистических причин, которые объясняют различия 
в употреблении и значении библейских фразеологизмов в двух языках [см.: Бетехтина 1995]. Сопоставительному анализу библеизмов в славянских и европейских языках посвятили свои труды многие ученые. Клюкина, например, пишет о влиянии Священного Писания на сознание русского человека, в результате которого появляются устойчивые фразы и выражения, закрепленные в языке [см.: Литературные аллюзии, образы и цитаты в английском языке: справочное пособие 1990]; Меликян, предпринял попытку «классифицировать фразеологические единицы библейского происхождения в рамках когнитивного подхода к языку по принципу основных видов и типов взаимодействия» и на основе этой классификации «построить структурно-семантическую классификацию фразеологических единиц английского языка библейского происхождения» по основополагающему основанию наличия или отсутствия непосредственного библейского прототипа [см.: Меликян 1998]; Степанова проводит сравнительный анализ библеизмов в русском, словацком и чешском литературных языках [см.: Степанова 1993], а в работе Лилич и Трофимкиной сопоставляются библеизмы в сербском и русском языках [см.: Лилич, Трофимкина 1998]. Сопоставительному анализу библеизмов в русском и иностранных языках посвящен ряд диссертационных работ молодых исследователей Мендельсона, Каминской, Жолобовой [см.: Мендельсон 2002, Каминская 2004, Жолобова 2005] и других.

Многочисленные работы посвящены функционированию библейской фразеологии в художественной и общественно-политической литературе, а также в языке СМИ. К примеру, исследователь Петров в 1998 году пишет о популярности Библии и обращению к библейским текстам, о библеизмах, которые повысили свою активность в художественных и публицистических текстах [см.: Петров 1998]. Также употреблению фразеологизмов библейского происхождения как проблеме культуры речи посвящены работы многочисленных исследователей [см.: Литвиненко 1991, Колесова 1993, Оноприенко 1997, Прибытько 2000, 2002, Бондарь 2003, Дубровина 2005, 2007 и др.].

Некоторые авторы затрагивают проблемы трансформации библейских фразеологизмов и употребления их для придания эмоционально-экспрессивных оттенков литературным и публицистическим текстам. Особо хотелось бы отметить работу исследователя Дубровиной, чья книга представляет собой научный труд в популярном, доступном изложении. В ней идет речь о библеизмах в русском и других европейских языках, а также об отражении библейских образов, сюжетов, идей, правовых и морально-этических норм и воззрений древнего Востока 
в культуре народов, исповедующих христианскую религию. Особое внимание здесь уделяется русской национальной культуре: использованию библейских слов и выражений в русском языке, в художественной и публицистической литературе, в музыкальном и изобразительном искусстве [см.: Дубровина 2012]. Большой интерес представляет собой экспериментальное диссертационное исследование Федотовой, так как оно является одной из немногочисленных работ психолингвистического характера. Автор в качестве эксперимента обращается к носителям русского языка с целью изучения особенностей «живого» понимания библейских фразеологизмов и делает интересные наблюдения и важные замечания в этой области [см.: Федотова 2000].

Все большее число исследователей обращается к проблеме прецедентности библейских выражений [см.: Кремнева 1999, Орлова 2008, 2010, Караулов 2019]. Авторы работ по данной тематике утверждают, что сама Библия представляет собой прецедентный текст, содержащий большое количество разнообразных прецедентных ситуаций, высказываний и имен. Видя необходимость в изучении проблемы прецедентности библеизмов, исследовательница Туркова-Зарайская утверждает, «библейские прецедентные феномены, наряду с остальными прецедентными феноменами, задают шкалу ценностных ориентаций лингво-культурного сообщества. Они помогают носителям языка ориентироваться в сложных понятиях, отражающих ключевые концепты культуры, являя собой эталонное воплощение абстракций» [Туркова-Зарайская 2000, 53]. Языковед Пыстина в статье «Функционирование библеизмов как прецедентных феноменов в современном медиатексте» предпринимает попытку выявить закономерности функционирования библеизмов в современных медиатекстах. С этой целью она рассматривает способы обращения к библеизмам как прецедентным феноменам в популярных средствах массовой информации религиозной и светской направленности [http://www.gramota.net/materials/2/ 2016/10-3/38.html].

Другие работы посвящены отдельным проблемам библейской фразеологии, раскрывающие истоки и этимологию некоторых выражений, освещающие новейшие научные открытия в этой области.

Нельзя не вспомнить о предпринятой рядом ученых в 1994 году попытке систематизировать рукописи В.В. Виноградова, которая была оформлена как книга История слов, представляющая собой ранее нигде не публиковавшийся труд, посвященный истории основных пластов русской лексики. В состав этой книги входят главы, посвященные происхождению более полутора тысяч русских слов и выражений, 
в том числе восходящих к общеславянской, церковнославянской лексике [см.: Виноградов 1994].

Среди исследований библейской тематики есть работы, имеющие методический характер. Большой интерес для преподавателей средних и высших учебных заведений представляет собой статья Супрун, содержащая практические рекомендации по преподаванию библейской истории и церковно-славянского языка [см.: Супрун 1995]. По нашему мнению, одним из самых значительных и обширных трудов конца XX века стала работа Мечковской, написанная в форме лекций, представляющих собой широкий обзор исторических, культурологических, социологических, фольклорных, литературоведческих и переводческих проблем, связанных с основными мировыми религиями [см.: Мечковская 1998]. Эта книга указывает на связь языков и древнейших религий мира (ведическая религия, иудаизм, конфуцианство, буддизм, христианство, ислам). В ней указаны особенности религиозного общения в различных культурах, влияние религии на историю языков, фольклора, литературных и филологических традиций. Читатель получает множество информации о церковных конфликтах, связанных с переводом и толкованием священных книг, о мифопоэтических истоках ранней и современной философии языка ${ }^{1}$.

Повышенный интерес исследователей Библии вызывает проблема перевода текстов Священного Писания. Были опубликованы статьи как общего характера, которые указывают на взаимоотношение стиля и смысла в канонических текстах, наблюдаемые при современном переводе Библии, а также на роль Библии в истории русской культуры [см.: Колесов 1990], так и работы, посвященные переводу библейских текстов на славянские языки, например, чешский [см.: Тугушева 1995], сербский, хорватский и словенский [см.: Тяпко 1995]. Клюкина пишет об особенностях употребления и перевода английских библеизмов [см.: Клюкина 2003], а в статье исследовательницы Мжельской представлен краткий обзор проблем, с которыми может столкнуться переводчик при передаче значения фразеологизмов библейской этимологии. Особое внимание уделяется переводу фразеологизмов с ономастическим компонентом. Исследовательница приводит несколько примеров семантической эволюции имен собственных в рус-

\footnotetext{
1 Данная научная работа, адресованная студентам гуманитарных факультетов вузов и колледжей, может быть использована при изучении курсов История и философия религии, Введение в общую филологию, Семиотика, Основы языкознания, Философия и история культуры, Сочиальная психология.
} 
ском и английском языках, произошедшей на основе приобретенных коннотаций [см.: Мжельская 2007].

Над проблемой перевода Библии с учетом необходимости приближения ее к простому читателю работают представители Российского Библейского Общества, которые также следят за всеми нарушениями библейской символики и стараются исключать ошибки в переводческом процессе. Председатель Синодальной библейско-богословской комиссии, профессор, митрополит Русской Православной Церкви Илларион в своем докладе «Переводы Библии: история и современность», изложенном на московской конференции «Современная библеистика u Предание Церкви» в ноябре 2013 года, говорил: «Современный перевод Библии немыслим без учета достижений мировой библейской науки. Это касается и текстологии, и знания древних реалий, и современной теории перевода. Синодальный перевод - это наше драгоценное достояние. Именно благодаря Синодальному переводу Библия 2 зазвучала и звучит на русском. Дальнейшие шаги по поновлению русской Библии необходимы и неизбежны».

Ряд ученых проводит активную работу по созданию фразеологических словарей, предназначенных для широкого круга читателей, которые сталкиваются с трудностями при прочтении художественной или публицистической литературы. Лексикографы знакомят читателей с контекстом Священного Писания, цитируя некоторых философов, лингвистов, литературоведов, истолковывая значение фразы или ее отдельных компонентов, иллюстрируя употребление библейских фразеологизмов литературными примерами. Так в публикации Грановской автор использует практику всевозможных толковых словарей и результаты исследований современных исследователей Библии, фрагменты которых печатаются в лингвистических журналах [см.: Грановская 1998]. Во фрагментах словаря Матвеевой и Макарова можно найти переводы слов и словосочетаний с древнееврейского или латинского

2 Учебная Библия или, по-другому, Библия с комментариями - это последнее издание Библии, опубликованное РБО в 2017 году, предназначенное для самого широкого круга читателей. Комментарии содержат лишь те сведения, которые считаются общепринятыми в мировой библейской науке, и нацелены на то, чтобы обеспечить читателю глубокое понимание текстов Священного Писания. Они освящают широкий историко-культурный контекст, раскрывают ключевые понятия Библии, объясняют основные религиозно-идейные концепты, подчеркивают связи между разными фрагментами Библии, указывают на текстологические и прочие проблемы, дают различные варианты интерпретации. Основная цель издания - представить Библию как живую и увлекательную книгу [http://www.patriarchia.ru/db/text/3394042.html]. 
языков, а также даты поминания святых и событий, связанных с определенным высказыванием [см.: Матвеева, Макаров 1995, 1996].

В публикациях Шанского [см.: Шанский 1996] «библеизмы не упорядочены в виде словаря, но параллель, приводимая автором между библейским значением и значением, приписываемым некоторому высказыванию сегодня, позволяет использовать данную статью в качестве такового. Языковед ограничивается лишь евангельским текстом и анализирует библеизмы с точки зрения их принадлежности к церковнославянской лексике или к языковым фактам, возникшим в русском языке или заимствованных из других языков» [Туркова-Зарайская 2000, 23].

Хотелось бы отметить, что нами замечены наиболее значимые работы из числа многочисленных научных исследований, посвященных данной тематике, и это в очередной раз подтверждает ее очевидную актуальность. Указывая на такое разнообразие и количество современных исследований, мы видим необходимость изучения связи русского языка и религии. В последние десятилетия на постсоветском пространстве все более возрастает интерес лингвистов к языку Библии, изучению религиозной картины мира. Не теряет своей актуальности изучение Священного Писания, а внимание многочисленных исследователей фокусируется на изучении фразеологических единиц библейской этимологии. В современных российских лингвистических исследованиях существует два подхода к изучению фразеологизмов библейского происхождения: отечественный и западнический. Их представители основывают свои работы на достижениях российских и зарубежных ученых. Тематика публикуемых исследований самая разнообразная: от философских, литературоведческих и лингвистических трудов, до статей культурологического и исторического характера. Посвященные фразеологизмам библейского происхождения работы - это в основном исследования общего плана, которые знакомят читателя с их употреблением в современных языках. Существуют работы классификационного и сопоставительного характера, созданные на материале нескольких языков, опыты создания словарей, а также многочисленные диссертационные исследования молодых ученых.

\section{Литература}

Betehtina E.N., 1995, Frazeologičeskie edinicy s antroponimičeskim komponentom biblejskogo proishoždenî̂a $v$ russkom $i$ anglijskom âzykah, [v:] Bibliâa $i$ vozroždenie duhovnoj kul'tury russkogo $i$ drugih slavânskih narodov, Sankt- 
Peterburg, s. 20-31. [Бетехтина Е.Н., 1995, Фразеологические единиць с антропонимическим компонентом библейского происхождения в русском и английском языках, [в:] Библия и возрождение духовной культуры русского и других славянских народов, Санкт-Петербург, с. 20-31].

Biblejskaâ ènciklopediâ, 1996, RBO, Moskva. [Библейская энциклопедия, 1996, РБО, Москва.]

Biblejskie issledovaniâ, sbornik statej, 1997, Moskva. [Библейские исследования, сборник статей, 1997, Москва.]

Bibliâ $i$ vozroždenie duhovnoj kultury russkogo i drugih slavânskih narodov, 1995, Sankt-Peterburg. [Библия и возрождение духовной культуры русского и других славянских народов, 1995, Санкт-Петербург.]

Birih A., Matešič J., 1998, Iz istorii russkih biblejskih vyraženij, „Russkij âzyk za rubežom”, № 5, 6, s. 41-47. [Бирих А., Матешич Й., 1998, Из истории русских библейских выражений, „Русский язык за рубежом”, № 5,6 , c. $41-47$.

Bondar' M., 2003, Bibleizmy kak istočnik povyšeniâ èkspressivnosti publicističeskogo teksta, „Žurnalistika i kul'tura russkoj reči”, № 1, s. 30-41. [Бондарь М., 2003, Библеизмы как источник повышения экспрессивности публицистического текста, „Журналистика и культура русской речи”, № 1 , c. $30-41$.

Vereŝagin E.M., 1993, Biblejskâ̂ stihiâ russkogo âzyka, „Russkaâ reč'”, № 1, s. 90-98. [Верещагин Е.М., 1993, Библейская стихия русского языка, „Русская речь", № 1, с. 90-98.]

Vinogradov V.V., 1994, Istoriâ slov, Moskva. [Виноградов В.В., 1994, История слов, Москва.]

Gak V.G., 1997, Osobennosti biblejskih frazeologizmov v russkom âzyke (v sopostavlenii s francuzskimi bibleizmami), „Voprosy âzykoznaniâ”, № 5, s. 58. [Гак В.Г., 1997, Особенности библейских фразеологизмов в русском языке (в сопоставлении с франиузскими библеизмами), „Вопросы языкознания", № 5, с. 58.]

Gak V.G., 1999, Desakralizaciâ bibleizmov v romanskih âzykah, [v:] Edinstvo i mnogoobrazie romanskogo mira, Sankt-Peterburg, s. 9-10. [Гак В.Г., 1999, Десакрализачия библеизмов в романских языках, [в:] Единство и многообразие романского мира, Санкт-Петербург, с. 9-10.]

Granovskaâ L.M., 1998, Biblejskie frazeologizmy (opyt slovarâ), „Russkaâ reč'”, № 1, s. 73-78; № 2, s. 73-80; № 3, s. 70-76; № 5, s. 75-79. [Грановская Л.М., 1998, Библейские фразеологизмы (опыт словаря), „Русская речь”, № 1, c. $73-78$; № 2, c. 73-80; № 3, с. 70-76; № 5, с. 75-79.]

Grigor'eva V., 2007, O putâh proniknoveniâ biblejskih frazeologizmov v russkij âzyk, „Russkij âzyk v škole”, № 6, s. 52-58. [Григорьев A.B., 2007, O nутяx npoникновения библейских фразеологизмов в русский язык, „Русский язык в школе", № 6 , с. 52-58.] 
Gubanov V.A., 1996, Bibliâ operežaet nauku na tysâči let, Moskva. [Губанов B.A., 1996, Библия опережает науку на тысячи лет, Москва.]

Dubrovina K.I., 2005, Lingvističeskie osnovy stilističeskih priëmov ispol'zovaniâ frazeologizmov v hudožestvennoj literature i publicistike, „Vestnik Rossijskogo universiteta drużby narodov", seriâ «Lingvistika», № 7, s. 100-118. [Дубровина К.И., 2005, Лингвистические основь стилистических приёмов использования фразеологизмов в художественной литературе и публииистике, „Вестник Российского университета дружбы народов”, серия «Лингвистика», № 7, с. 100-118.]

Dubrovina K.N., 2007, Bibliâa $i$ russkie frazeologizmy, „Russkaâ reč'”, № 2, s. 86-93. [Дубровина К.Н., 2007, Библия и русские фразеологизмьи, „Русская речь", № 2, с. 86-93.]

Dubrovina K.N., 2012, Biblejskie frazeologizmy v russkoj i evropejskoj kul'ture, Moskva. [Дубровина K.Н., 2012, Библейские фразеологизмы в русской и европейской культуре, Москва.]

Žolobova A.O., 2005, Frazeologičeskie edinicy biblejskogo proishoždenî̂a v anglijskom, ispanskom i russkom âzykah, Diss.... k. f. n., Kazan'. [Жолобова А.О., 2005, Фразеологические единиџь библейского происхождения в английском, испанском и русском языках, Дисс.... к. ф. н., Казань.]

Izvestiâ Biblejskih Komissij, 1990, vyp. 1, 2, Sankt-Peterburg. [Известия Библейских Комиссий, 1990, вып. 1, 2, Санкт-Петербург.]

Kaminskaâ E.V., 2004, Frazeologiâ biblejskogo proishoždeniâ vo francuzskom i russkom âzykah, Dis.... k. f. n., Sankt-Peterburg. [Каминская Е.В., 2004, Фразеология библейского происхождения во французском и русском языках, Дис.... к. ф. н., Санкт-Петербург.]

Karaulov Û.N., 2019, Russkij âzyk i âzykovâ̂ ličnost', Moskva. [Караулов Ю.Н., 2019, Русский язык и языковая личность, Москва.]

Klimovič N.V., 2006, K voprosu ob opredelenii bibleizma v lingvistike, [v:] Âzykoznanie, Krasnoârsk, s. 11-20. [Климович Н.В., 2006, K вопросу об определении библеизма в лингвистике, [в:] Языкознание, Красноярск, с. 11-20.]

Klûkina T.P., 2003, Osobennosti upotrebleniâ iperevoda anglijskih $i$ russkih bibleizmov, „Stolpotvorenie”, № 8-9. [Клюкина Т.П., 2003, Особенности употребления и перевода английских и русских библеизмов, „Столпотворение", № 8-9.]

Kolesov V.V., 1990, Narušenie stilâ $i$ razrušenie smysla v sovremennyh perevodah Biblejskih tekstov, [v:] Bibliâ ivozroždenie duhovnoj kul'tury russkogo i drugih slavânskih narodov, Sankt-Peterburg, s. 81-105. [Колесов В.В., 1990, Нарушение стиля и разрушение смысла в современных переводах Библейских текстов, [в:] Библия и возрождение духовной культурь русского и других славянских народов, Санкт-Петербург, с. 81-105.]

Kolesov V.V., 1993, Prazdnoe slovo, „Russkaâ slovesnost'”, № 3. [Колесов В.В., 1993, Праздное слово, „Русская словесность”, № 3.] 
Komissiâ po naučnomu izdanî̂ Slavânskoj Biblii (Russkâ̂ Biblejskâ̂ Komissiâ), 1990, Sbornik arhivnyh materialov, sost. K.I. Logačev, Sankt-Peterburg. [Koмиссия по научному изданию Славянской Библии (Русская Библейская Комиссия), 1990, Сборник архивных материалов, сост. К.И. Логачев, Санкт-Петербург.]

Kremneva A.V., 1999, Funkcionirovanie biblejskogo mifa kak precedentnogo teksta, Diss... k.f.n., Barnaul. [Кремнева A.B., 1999, Функиионирование библейского мифа как прецедентного текста, Дисс... к.ф.н., Барнаул.]

Larson M., 1993, Smyslovoj perevod. Rukovodstvo po teorii mež"âzykovoj èkvivalentnosti $i$ ee praktičeskomu primeneniû, Sankt-Peterburg. [Ларсон М., 1993, Смицловой перевод. Руководство по теории межъязыковой эквивалентности и ее практическому применению, Санкт-Петербург.]

Lilič G.A., 1995, Bibleizmy kak otraženie vozzrenij èpohi, [v:] Bibliâ i vozroždenie duhovnoj kul'tury russkogo $i$ drugih slavânskih narodov, Sankt-Peterburg. [Лилич Г.А., 1995, Библеизмы как отражение воззрений эпохи, [в:] Библия и возрождение духовной культурь русского и других славянских народов, Санкт-Петербург.]

Lilič G.A., Trofimkina O.I., 1998, Bibleizmy v sovremennom russkom i serbskom âzykah, [v:] Izučenie slavânskih âzykov, literatur i kul'tur v inoslavânskoj srede, Belgrad, s. 275-278. [Лилич Г.А., Трофимкина О.И., 1998, Библеизмь в современном русском и сербском языках, [в:] Изучение славянских языков, литератур и культур в инославянской среде, Белград, с. 275-278.]

Litvinenko A.N., 1991, Voskrešenie slova, „Russkaâ reč'”, № 6. [Литвиненко А.Н., 1991, Воскрешение слова, „Русская речь”, № 6.]

Literaturnye allûzii, obrazy $i$ citaty $v$ anglijskom âzyke: spravočnoe posobie, sost. T.P. Klûkina, 1990, VKIÂA MID SSSR, Moskva. [Литературные аллюзии, образы и иитаты в английском языке: справочное пособие, сост. Т.П. Клюкина, 1990, ВКИЯ МИД СССР, Москва.]

Matveeva N.P., Makarov V.I., 1995, Bibleizmy v russkoj slovesnosti (fragmenty slovarâ), „Russkaâ slovesnost'”, № 3, s. 87-91; 1996, № 1, s. 8-85; № 2, s. 88-90. [Матвеева Н.П., Макаров В.И., 1995, Библеизмьл в русской словесности (фрагменты словаря), „Русская словесность”, № 3, с. 87-91; 1996, № 1, c. 81-85; № 2, c. 88-90.]

Melikân A.A., 1998, Klassifikaciâ biblejskih frazeologizmov anglijskogo âzyka na osnove konceptual'nyh modelej preobrazovaniâ znaniâ v semantičeskie edinicy âzyka, Diss.... k. f. n., Pâtigorsk. [Меликян А.А., 1998, Классификация библейских фразеологизмов английского языка на основе кониептуальньх моделей преобразования знания в семантические единиць языка, Дисс.... к. ф. н., Пятигорск.]

Mendel'son V.A., 2002, Frazeologičeskie edinicy biblejskogo proishoždeniâ v anglijskom i russkom âzykah, Kazan'. [Мендельсон В.А., 2002, Фразеологические единиць библейского происхождения в английском и русском языках, Казань.] 
Mečkovskaâ N.B., 1998, Âzyk i religiâ. Lekcii po filologii $i$ i storii religij, Moskva. [Мечковская Н.Б., 1998, Язык и религия. Лекиии по филологии и истории религий, Москва.]

Mžel'skaâ O.K., 2007, Aktual'nye problemy perevoda bibleizmov, „Omskij naučnyj vestnik", № 2, s. 151-152. [Мжельская О.К., 2007, Актуальные проблемь перевода библеизмов, „Омский научный вестник”, № 2, с. 151-152.]

Mokienko V.M., 1995, Frazeologičeskie bibleizmy v sovremennom tekste, [v:] Bibliâ $i$ vozroždenie duhovnoj kul'tury russkogo $i$ drugih slavânskih narodov, Sankt-Peterburg, s. 143-158. [Мокиенко B.M., 1995, Фразеологические библеизмы в современном тексте, [в:] Библия и возрождение духовной культуры русского и других славянских народов, Санкт-Петербург, c. $143-158$.

Onoprienko S., 1997, Bibleizmy sovremennogo russkogo âzyka, Diss. ... k. f. n., Voronež. [Оноприенко C., 1997, Библеизмы современного русского языка, Дисс. ... к. ф. н., Воронеж.]

Orlova N.M., 2008, Precedentnye fenomeny biblejskogo istoka v russkoj filologičeskoj tradicii, „Vestnik TGU”, vyp. 5 (61), s. 196-194. [Орлова Н.М., 2008, Прецедентные феномены библейского истока в русской филологической традиции, „Вестник ТГУ”, вып. 5 (61), с. 196-194.]

Orlova N.M., 2010, Biblejskij tekst kak precedentnyj fenomen, Diss. ... k. f. n., Saratov. [Орлова Н.М., 2010, Библейский текст как прецедентный феномен, Дисс. ... к. ф. н., Саратов.]

Petrov V.K., 1998, Krylatye vyraženiâ v sovremennom russkom âzyke, Komsomol'sk-na-Amure. [Петров В.К., 1998, Крылатые выражения в современном русском языке, Комсомольск-на-Амуре.]

Pribyt'ko E.N., 2000, Ošibki v upotreblenii bibleizmov na gazetnoj polose, [v:] Novoe v massovoj kommunikacii, vyp. 1-2, Voronež. [Прибытько Е.Н., 2000, Ошибки в употреблении библеизмов на газетной полосе, [в:] Новое в массовой коммуникации, вып. 1-2, Воронеж.]

Pribyt'ko E.N., 2002, Bibleizmy v âzyke sovremennyh gazet, Diss. ... k. f. n., Voronež. [Прибытько Е.Н., 2002, Библеизмы в языке современных газет, Дисс. ... к. ф. н., Воронеж.]

Stepanova A.A., 1993, Bibleizmy v russkom, češskom i slovackom literaturnyh âzykah, Moskva. [Степанова А.А., 1993, Библеизмь в русском, чешском и словачком литературных языках, Москва.]

Suprun V.I., 1995, Biblejskij tekst na zanâtiâh v škole $i$ VUZE, [v:] Bibliâa $i$ vozroždenie duhovnoj kul'tury russkogo i drugih slavânskih narodov, SanktPeterburg, s. 159-165. [Супрун В.И., 1995, Библейский текст на занятиях в школе и ВУЗе, [в:] Библия и возрождение духовной культурь русского и других славянских народов, Санкт-Петербург, с. 159-165.]

Tuguševa R.H., 1995, Ob odnom perevode na češskij âzyk biblejskogo teksta, [v:] Bibliâ $i$ vozroždenie duhovnoj kul'tury russkogo $i$ drugih slavânskih narodov, Sankt-Peterburg, s. 187-196. [Тугушева P.X., 1995, Об одном переводе на 
чешский язык библейского текста, [в:] Библия и возрождение духовной культуры русского и других славянских народов, Санкт-Петербург, c. $187-196$.

Turkova-Zarajskaâ M.O., 2000, Osobennosti ponimaniâ bibleizmov sovremennymi nositelâmi âzyka, Diss... k. f. n., Tver'. [Туркова-Зарайская M.O., 2000, Особенности понимания библеизмов современными носителями языка, Дисс... к. ф. н., Тверь.]

Tâpko G.G., 1995, O perevodah Biblii u serbov, horvatov $i$ slovencev do XX veka (sopostavitel'nyj obzor), [v:] Bibliâ ivozroždenie duhovnoj kul'tury russkogo $i$ drugih slavânskih narodov, Sankt-Peterburg, s. 197-213. [Тяпко Г.Г., 1995, $O$ переводах Библии у сербов, хорватов и словенчев до XX века (сопоставительный обзор), [в:] Библия и возрождение духовной культуры русского и других славянских народов, Санкт-Петербург, с. 197-213.]

Fedotova S.V., 2000, Biblejskij mif kak konvencional'nyj stereotip: èksperimental'noe issledovanie, Diss.... k. f. n., Barnaul. [Федотова C.В., 2000, Библейский миф как конвенциональный стереотип: экспериментальное исследование, Дисс.... к. ф. н., Барнаул.]

http://www.gramota.net/materials/2/2016/10-3/38.html, [25.02.2019].

http://www.patriarchia.ru/db/text/3394042.html, [25.02.2019].

STUDYING BIBLICAL IDIOMS IN THE RUSSIAN LANGUAGE AN OVERVIEW OF THE MOST IMPORTANT RESEARCH APPROACHES

ABSTRACT

Key words: the Bible, Russian language, biblical phraseology, linguistic research, national culture

In recent decades, in the post-Soviet area, an interest of linguists in religious subjects has been increasing. Linguists undertake a large-scale research on the religious image of the world. Studying the Bible gains in importance, and the attention of many researchers focuses on the multi-facited description of phraseological units of the biblical origin. In contemporary Russian linguistic analyzes, there are two approaches to the study of phraseological expressions of biblical provenance: in accordance with the Russian or western research traditions. Representatives of both fields of study refer in their works to the achievements of Russian or foreign scientists. The resulting studies are typologically diversified. Among them you can find literary, philosophical and linguistic works, articles of historical and cultural character, descriptive and comparative works (created on the basis of material from several languages), experimental dictionary publications and other types of scientific texts. The present article is a presentation of the most important, in my opinion, works on the religious image of the world. 